\title{
Investigation of Risk Factors and Biosecurity Measures Associated with Prevalence of Newcastle Disease Virus in Broiler Farms
}

\author{
Mirza Mienur Meher ${ }^{1, a, *}$, Jaisan Islam ${ }^{2, b}$, Marya Afrin ${ }^{3, c}$ \\ ${ }^{I}$ Department of Microbiology and Public Health, Faculty of Veterinary Medicine and Animal Science, Bangabandhu Sheikh Mujibur \\ Rahman Agricultural University, Gazipur-1706, Bangladesh. \\ ${ }^{2}$ Department of Microbiology and Public Health, Faculty of Animal Science and Veterinary Medicine, Patuakhali Science and Technology \\ University, Patuakhali, Bangladesh. \\ ${ }^{3}$ Department of Anatomy and Histology, Faculty of Veterinary Science, Bangladesh Agricultural University, Mymensingh-2202, \\ Bangladesh. \\ *Corresponding author
}

A R T I C L E I N F O A B S T R A C T

Research Article

Received : 27/06/2020

Accepted : 04/09/2020
Newcastle disease (ND) is one of the major viral diseases of poultry, remains a constant threat in poultry farms that causes huge economic losses every year. However, little is known regarding the potential risk factors of the disease in broiler. The study was undertaken to ascertain the potential risk factors and biosecurity measures in ND prevalent broiler farm. A total of 116 broiler farms were considered as a sample size from a different area of Barishal district of Bangladesh in which $19.83 \%$ ND prevalence was found. In the findings, the farmers $(33.62 \%)$ who had training on poultry farming, were significantly less ND positive case (7.69\%). Besides this, among the different risk factors and biosecurity measures only shed location, ventilation, vaccination status, feeder and waterer cleaning frequency, visitors accession, pets in the farm, use of disinfectant and seasonal variation had significant effect on ND outbreak. However, among all the factors only farmers training (OR=0.025; 95\% CI: 0.001-0.509), shed location $(\mathrm{OR}=0.035 ; 95 \%$ CI: $0.003-0.390)$, vaccination against $\mathrm{ND}(\mathrm{OR}=0.017 ; 95 \% \mathrm{CI}$ : 0.001-0.435) and use of disinfectant daily $(\mathrm{OR}=0.011$; 95\% CI: 0.000-0.294) made a unique statistically significant contribution to the regression model and the predictors had approximately similar strength on reporting ND outbreak. In completion, ND can be reduced in broiler farms by improving the level of common biosecurity, farm management practices, and minimizing the potential risk factors through training of farmers, awareness buildup, and enforcement of these practices on the farms.

\begin{tabular}{l|l} 
Keywords: & variation had significant effect on ND outbreak. However, among all the factors only farmers \\
Risk-factor & training (OR=0.025; 95\% CI: 0.001-0.509), shed location (OR=0.035; 95\% CI: 0.003-0.390), \\
Biosecurity & vaccination against ND (OR=0.017; 95\% CI: 0.001-0.435) and use of disinfectant daily (OR=0.011; \\
Newcastle disease & $\begin{array}{l}95 \% \text { CI: } 0.000-0.294) \text { made a unique statistically significant contribution to the regression model } \\
\text { and the predictors had approximately similar strength on reporting ND outbreak. In completion, ND } \\
\text { Prevalence } \\
\text { Broiler }\end{array}$ \\
$\begin{array}{l}\text { can be reduced in broiler farms by improving the level of common biosecurity, farm management } \\
\text { practices, and minimizing the potential risk factors through training of farmers, awareness build- } \\
\text { up, and enforcement of these practices on the farms. }\end{array}$
\end{tabular}

\section{Introduction}

Poultry farming is one of the fast-growing sectors in Bangladesh, plays important role in socio-economic development (Al-Mamun et al., 2019). In the face of the rapid growth of this industry, it is rendered to certain diseases especially viral diseases (Karim 2003). Among the infectious agents, Newcastle disease (ND) is revealed as the significant viral disease of poultry in the world especially in developing countries (Rahaman et al., 2011). The etiological agent of ND is the Newcastle disease virus (NDV), avian paramyxovirus serotype 1 (APMV-1) of the genus Avulavirus belonging to the family Paramyxoviridae (Dimitrov et al., 2016).

In Bangladesh, ND is locally familiar as 'Ranikhet' disease (RD) and is highly contagious that susceptible to many species of domestic as well as wild birds (Al-Garib et al. 2003). As is observed, high mortality, morbidity, stress, decreased egg production, and hatchability are the most common in NDV infection, leads to high economic losses (Alexander, 2000). After that, NDV induces mortality up to $100 \%$ with or without clinical signs, even amongst vaccinated poultry as a result of faulty administration of vaccine (Chukwudi et al., 2012). The more important is, no treatment for NDV exists, only the use of prophylactic vaccines and biosecurity measures can reduce the likelihood of outbreaks (Orajaka et al., 1999).

Furthermore, several studies narrated the usual transmission of ND from farm to farm through live infected birds, selling or giving away sick birds, inhalation of the virus from contaminated air, and ingestion of contaminated feed and water (Ibitoye et al., 2013). Besides this, the farm equipment, feeder, waterer, clothing, litter or any others contaminated by the exposure to excretions from infected birds have been reported as a potential risk factor of ND transmission (Tu et al., 1998). Additionally, poor 
biosecurity measures enhance the transmission leads to an outbreak. Biosecurity aimed at keeping the farms or areas out of viruses, basically all contagious diseases (Swayne and Jackwood, 2008). Nevertheless, in commercial poultry production systems, most of the case minimum biosecurity is practiced or in some cases non-existing and this may drive to the spread of multiple infections within or between farms (Permin, 1997). In commercial poultry farms, faulty disposal of dead poultry and used litter, multi-aged and multi-species poultry on the same farm, poor farm traffic control and sanitation were major biosecurity risks (Ameji et al., 2012; Wakawa et al., 2012). Though during the last few years several emerging diseases and unknown causes threaten the poultry industry and cause huge loss to the farmers (Al-Mamun et al., 2019), indeed that the farmers are not entirely aware of the most important viral diseases of poultry like ND. However, the current information on the occurrence of ND in the broiler, as well as the potential risk factors for the disease in the Barishal district of Bangladesh is limited. Besides this, current reports on biosecurity measures in broiler farms along with farmer's demographic data are insufficient. Meanwhile, updated information is essential for analysis on the epidemiology of ND in broiler to design prevention and control strategies throughout the country. Therefore, this study was aimed to ascertain the prevalence of ND in broiler associated with potential risk factors and biosecurity measures in herdlevel as well as the farmer's demographic information in the Barishal district of Bangladesh.

\section{Materials and Methods:}

This study was conducted in different areas (Figure 1) of Barishal district of Bangladesh during the period of May 2017 to July 2018. The spatial location of the study sites was identified in the map (Figure 1) using ArcGIS-ArcMap version 10.8 (ESRI, USA) software. Data were collected through an interview schedule involving 116 respondents who were involved in broiler farming. Respondents were randomly selected from different parts of the Barishal district for collecting data to address the objectives. In this study, 116 respondents were interviewed to find out their socio-economic condition associated with the risk factor enhancing the outbreak of ND.

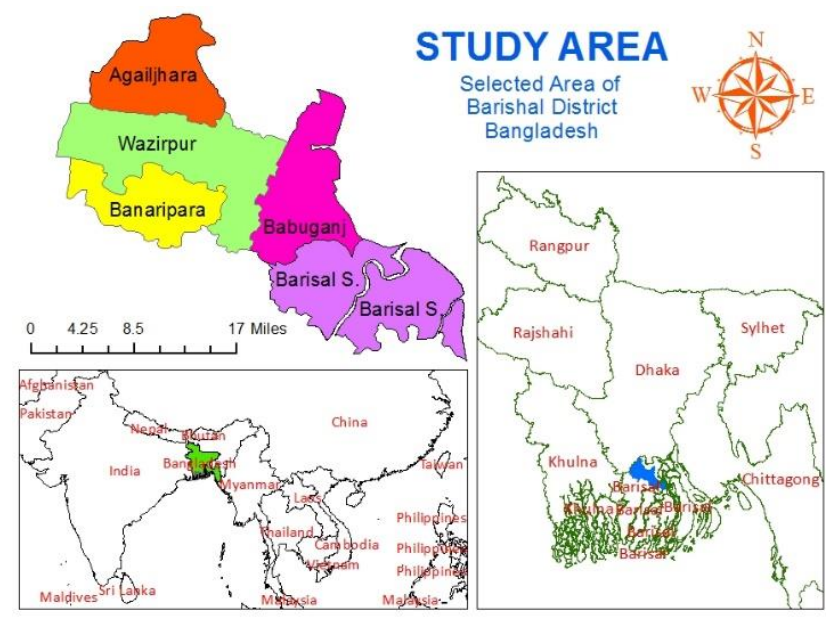

Figure 1. Geographical location of the study areas
Data were collected following the direct interviews by using a previously formed questionnaire that was designed by following the methods described by Thrushfield (2005). Interviews were normally conducted in the respondent's house during their leisure time by following a 'face to face' method. Major focal points of the interview were the general information about the farmers, the number of farms and birds, management of broiler farm, feed source, use of antibiotics, vaccination practice, farm biosecurity, Newcastle disease with its mortality, infectivity and risk factors with the also fundamental idea on the rearing of broiler. Problems and probable solutions related to broiler production were also focused. According to the climatic conditions of Bangladesh, the year was divided into three seasons namely summer, rainy, and winter. The Summer season was considered from March to June, rainy season from July to October, and winter was considered from November to February.

\section{Clinical Diagnosis of ND}

The Clinical diagnosis was made on the basis of clinical history from the responsible persons of the farms, recorded clinical signs, and gross lesions of affected chickens. The post-mortem examination of birds was performed and ND was diagnosed according to post-mortem findings which is similar to Hasan et al. (2012).

\section{Statistical Analysis}

The data obtained from the study were entered and arranged accordingly into a spreadsheet (Microsoft Excel2010) and then transferred into Statistical Package for Social Sciences (SPSS) version 25.0 for analysis. Proportionality of outbreak of ND in broiler farm with the potential risk factors and farmer's demographic information were computed by Pearson's Chi-square. On the other hand, when more than $20 \%$ of cells of $2 \times 2$ contingency table had expected count less than 5 , the pvalue of continuity correction was considered but when the table was not $2 \times 2$ contingency then $p$ value of Fisher exact tests was accounted. Among all variables, those with $\mathrm{P}<0.05$ were subsequently considered for the Binary logistic regression model to screen the association between outcome variable (ND status) and all factors as well as farmer's status. All p-value $\mathrm{P}<0.05$ was considered statistically significant. And lastly, the final Hosmer and Lemeshow-of-fit test were performed to estimate the model for the goodness of fit (Ibrahim et al., 2019).

\section{Result and Discussion}

The findings of this study revealed that the prevalence of ND was $19.83 \%$ in broiler in Barishal district; with evidence of some potential risk factors and common practices at the farm level. However, the finding was a little bit of higher than reported by Hasan et al. (2012) and Das et al. (2018) where they reported $14.89 \%$ and $8.9 \%$ respectively. On the other hand, Rahman et al. (2011) was found that $23 \%$ ND prevalence in broiler which is some extent of higher than our findings. This variation may be due to different geographical locations with sample sizes.

Table 1, shows the demographic data of farmers indicated that among all the variables only the training status of the farmer had significant $(\mathrm{P}<0.05)$ association 
with ND positive case in broiler. In our findings, $33.62 \%$ of the farmers had training on poultry farming, among them only a small proportion $(7.69 \%)$ was in ND positive case whether $25.97 \%$ farmers of who had no training on poultry farming was in ND positive case. These findings have a close association with Alam et al. (2016) who reported that only $27.5 \%$ of the farmers had received training on poultry farming. Among the broiler farmer, $79.31 \%$ of them were male in comparison $(\mathrm{P}>0.05)$ to females $(20.69 \%)$. Though, our findings are close to Islam et al. (2019) where he reported that $18.2 \%$ of rural women had high participation in poultry farming but the findings of Belgrad et al. (2018) was completely reverse than our findings. This may be due to the variation in the socioeconomic conditions in different regions. The people involved in broiler farming in the studied area, the majority $(36.28 \%)$ of them aged between $\geq 30$ to $<40$ years that are closely related to the findings of Shahjahan \& Bhuiyan, (2016). On other hand, the highest proportion $(35.34 \%)$ of farmers were SSC passed whereas M. Rahman et al. (2002) found $71.43 \%$ and $24.29 \%$ of the farmers have a high and medium level of knowledge respectively, but Islam et al., (2019) stated that $43.6 \%$ of women farmers had secondary education. The findings of educational status may have variation due to different socioeconomic statuses in different region and may also have their different sample size. However, in our study, the variable "educational status" had no significant $(\mathrm{P}>0.05)$ association with ND outbreak (Table 1). In our findings, most of the farmers $(37.93 \%)$ were engaged in farming about $>5$ to $\leq 10$ years, but Belgrad et al. (2018) narrated that $46.5 \%$ of farmers had 3 to 12 years' experience on farming. Additionally, he also reported that $47.3 \%$ of farmer's main occupation was self-business. In which, we found highest number of farmers $(46.55 \%)$ main profession was other than agriculture and services, in this context the findings have a little bit of similarities.
In the study area, the farming condition was considered to determine the ND outbreak in broiler. Among the entire four variables, only two variables (broiler shed location and ventilation facilities) had significant $(\mathrm{P}<0.01$ and $\mathrm{P}<0.05$ respectively) association with ND outbreak (Table 2 ). The result indicated that, the farm located inside the home yard had approximately five times higher ND positive case $(46.88 \%)$ than located outside (Table 2). Moreover, the farm had sufficient ventilation, reduced the ND case to $13.51 \%$ whereas the farm with insufficient ventilation had $30.95 \%$ of ND positive case. Studies have shown that $21.7 \%$ of farm had no ventilation (Belgrad et al., 2018). Though in rural area are more prone to conventional farming, our data indicated that conventional farming systems were more ND positive cases $(24.05 \%)$ than the modern farming system.

The potential risk factor analysis was performed at the farm level. At the same time, the age of birds and seasonal influence were also analyzed to ascertain their rapport with ND exposure in broiler farms. In our findings, among the studied risk factor, only two factors including vaccination status and seasonal influence had a significant association with ND outbreak by, $\mathrm{P}<0.05$ and $\mathrm{P}<0.01$ respectively (Table 3). Broiler farms with no vaccination status had $62.96 \%$ of ND positive case, which is close to the findings of other authors (Das et al., 2018) report of $68.7 \%$ positive for ND in broiler. On the other side, our data indicated the rainy season had the highest proportion of ND positive cases $(35.48 \%)$ and the summer the lowest $(12.24 \%)$. The findings of Rahman and Adhikary (2016) also suggested our result, whereas Islam et al. (2003) reported that ND was higher in summer in comparison to the rainy and winter season. The issue of the seasonal prevalence is controversial and may vary according to the environmental, nutritional, and socioeconomic conditions, under which poultry is kept.

Table 1. Frequencies of ND in broiler according to poultry farmers' demographic characteristics.

\begin{tabular}{|c|c|c|c|c|c|c|c|c|}
\hline \multirow{3}{*}{ Variables } & \multirow{3}{*}{ Category Level } & \multirow{2}{*}{\multicolumn{2}{|c|}{ RSF }} & \multicolumn{4}{|c|}{ ND Status } & \multirow{3}{*}{$\begin{array}{c}\mathrm{P} \\
\text { Value }\end{array}$} \\
\hline & & & & \multicolumn{2}{|c|}{$\mathrm{n}=116$} & \multicolumn{2}{|c|}{$\%$} & \\
\hline & & (n) & $\%$ & $\mathrm{~N}$ & $\mathrm{P}$ & $\mathrm{N}$ & $\mathrm{P}$ & \\
\hline \multirow{5}{*}{ Age (Years) } & Less than 20 years & 6 & 5.17 & 4 & 2 & 66.67 & 33.33 & \multirow{5}{*}{$0.567^{\mathrm{c}}$} \\
\hline & From $\geq 20$ to $<30$ & 21 & 18.10 & 18 & 3 & 85.71 & 14.29 & \\
\hline & From $\geq 30$ to $<40$ & 42 & 36.21 & 34 & 8 & 80.95 & 19.05 & \\
\hline & From $\geq 40$ to $<50$ & 35 & 30.17 & 29 & 6 & 82.86 & 17.14 & \\
\hline & $\geq 50$ years & 12 & 10.34 & 8 & 4 & 66.67 & 33.33 & \\
\hline \multirow{2}{*}{ Sex } & Male & 92 & 79.31 & 74 & 18 & 80.43 & 19.57 & \multirow{2}{*}{$1.000^{\mathrm{b}}$} \\
\hline & Female & 24 & 20.69 & 19 & 5 & 79.17 & 20.83 & \\
\hline \multirow{5}{*}{ Education } & Illiterate & 5 & 4.31 & 3 & 2 & 60.00 & 40.00 & \multirow{5}{*}{$0.529^{c}$} \\
\hline & Primary & 22 & 18.97 & 16 & 6 & 72.73 & 27.27 & \\
\hline & Secondary & 41 & 35.34 & 33 & 8 & 80.49 & 19.51 & \\
\hline & Higher Secondary & 34 & 29.31 & 29 & 5 & 85.29 & 14.71 & \\
\hline & Bachelor and above & 14 & 12.07 & 12 & 2 & 85.71 & 14.29 & \\
\hline \multirow{2}{*}{ Farmers Training } & No & 77 & 66.38 & 57 & 20 & 74.03 & 25.97 & \multirow{2}{*}{$0.020^{\mathrm{a}}$} \\
\hline & Yes & 39 & 33.62 & 36 & 3 & 92.31 & 7.69 & \\
\hline \multirow{4}{*}{$\begin{array}{l}\text { Experience on } \\
\text { poultry farming } \\
\text { (Years) }\end{array}$} & $<1$ & 7 & 6.03 & 4 & 3 & 57.14 & 42.86 & \multirow{4}{*}{$0.342^{\mathrm{a}}$} \\
\hline & From $>1$ to $\leq 5$ & 39 & 33.62 & 30 & 9 & 76.92 & 23.08 & \\
\hline & From $>5$ to $\leq 10$ & 44 & 37.93 & 37 & 7 & 84.09 & 15.91 & \\
\hline & $>10$ & 26 & 22.41 & 22 & 4 & 84.62 & 15.38 & \\
\hline \multirow{3}{*}{$\begin{array}{l}\text { Farmers main } \\
\text { occupation }\end{array}$} & Agriculture & 46 & 39.66 & 41 & 5 & 89.13 & 10.87 & \multirow{3}{*}{$0.146^{\mathrm{a}}$} \\
\hline & Service & 16 & 13.79 & 12 & 4 & 75.00 & 25.00 & \\
\hline & Other than agriculture and services & 54 & 46.55 & 40 & 14 & 74.07 & 25.93 & \\
\hline
\end{tabular}

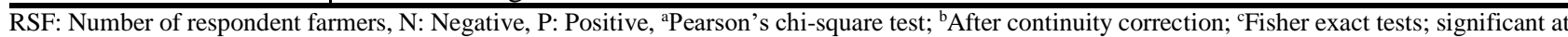
$1 \%(\mathrm{P}<0.01)$, Significant at $5 \%(\mathrm{P}<0.05) ; \mathrm{N}=$ Number. 
Table 2. Frequencies of ND in broiler according to broiler farm characteristics.

\begin{tabular}{|c|c|c|c|c|c|c|c|c|}
\hline \multirow{3}{*}{ Variables } & \multirow{3}{*}{ Category Level } & \multirow{2}{*}{\multicolumn{2}{|c|}{ RSF }} & \multicolumn{4}{|c|}{ ND Status } & \multirow{3}{*}{ P-Value } \\
\hline & & & & \multicolumn{2}{|c|}{$\mathrm{n}=116$} & \multicolumn{2}{|c|}{$\%$} & \\
\hline & & (n) & $\%$ & $\mathrm{~N}$ & $\mathrm{P}$ & $\mathrm{N}$ & $\mathrm{P}$ & \\
\hline \multirow{2}{*}{ Farming System } & Conventional & 79 & 68.10 & 60 & 19 & 75.95 & 24.05 & \multirow{2}{*}{$0.096^{\mathrm{a}}$} \\
\hline & Modern & 37 & 31.90 & 33 & 4 & 89.19 & 10.81 & \\
\hline \multirow{3}{*}{$\begin{array}{l}\text { Housing Floor } \\
\text { Condition }\end{array}$} & Mud Poultry House & 5 & 4.31 & 3 & 2 & 60.00 & 40.00 & \multirow{3}{*}{$0.326^{\mathrm{c}}$} \\
\hline & Concrete & 34 & 29.31 & 29 & 5 & 85.29 & 14.71 & \\
\hline & Bamboo/Wood & 77 & 66.38 & 61 & 16 & 79.22 & 20.78 & \\
\hline \multirow{2}{*}{$\begin{array}{l}\text { Broiler Shed } \\
\text { Location }\end{array}$} & Inside & 32 & 27.59 & 17 & 15 & 53.13 & 46.88 & \multirow{2}{*}{$0.000^{\mathrm{a}}$} \\
\hline & Outside & 84 & 72.41 & 76 & 8 & 90.48 & 9.52 & \\
\hline \multirow{2}{*}{ Ventilation } & Insufficient & 42 & 36.21 & 29 & 13 & 69.05 & 30.95 & \multirow{2}{*}{$0.024^{\mathrm{a}}$} \\
\hline & Sufficient & 74 & 63.79 & 64 & 10 & 86.49 & 13.51 & \\
\hline
\end{tabular}

RSF: Number of respondent farmers, N: Negative, P: Positive, ${ }^{\mathrm{a} P e a r s o n ' s ~ c h i-s q u a r e ~ t e s t ; ~}{ }^{\mathrm{b}}$ After continuity correction; ${ }^{\mathrm{c}}$ Fisher exact tests; Significant at $1 \%(\mathrm{P}<0.01)$, Significant at $5 \%(\mathrm{P}<0.05)$; $\mathrm{n}=$ Number.

Table 3. Potential Risk Factor for ND Status Associated with Broiler Farm.

\begin{tabular}{|c|c|c|c|c|c|c|c|c|}
\hline \multirow{3}{*}{ Variables } & \multirow{3}{*}{ Category Level } & \multirow{2}{*}{\multicolumn{2}{|c|}{ RSF }} & \multicolumn{4}{|c|}{ ND Status } & \multirow{3}{*}{ P-Value } \\
\hline & & & & \multicolumn{2}{|c|}{$\mathrm{n}=116$} & \multicolumn{2}{|c|}{$\%$} & \\
\hline & & (n) & $\%$ & Negative & Positive & Negative & Positive & \\
\hline \multirow{3}{*}{$\begin{array}{l}\text { Vaccination } \\
\text { status }\end{array}$} & No & 27 & 23.28 & 10 & 17 & 37.04 & 62.96 & \multirow{3}{*}{$0.000^{\mathrm{a}}$} \\
\hline & Only ND Vaccine & 26 & 22.41 & 23 & 3 & 88.46 & 11.54 & \\
\hline & $\mathrm{ND}+$ Other Vaccine & 63 & 54.31 & 60 & 3 & 95.24 & 4.76 & \\
\hline \multirow{3}{*}{ Types of Feed } & Ready Feed & 105 & 90.52 & 86 & 19 & 81.90 & 18.10 & \multirow{3}{*}{$0.186^{\mathrm{c}}$} \\
\hline & Handmix & 4 & 3.45 & 3 & 1 & 75.00 & 25.00 & \\
\hline & Local & 7 & 6.03 & 4 & 3 & 57.14 & 42.86 & \\
\hline \multirow{3}{*}{$\begin{array}{l}\text { Use of } \\
\text { Antibiotics }\end{array}$} & No & 33 & 28.45 & 26 & 7 & 78.79 & 21.21 & \multirow{3}{*}{$0.856^{\mathrm{a}}$} \\
\hline & Yes & 75 & 64.66 & 60 & 15 & 80.00 & 20.00 & \\
\hline & Others & 8 & 6.90 & 7 & 1 & 87.50 & 12.50 & \\
\hline \multirow{3}{*}{$\begin{array}{l}\text { Seasonal } \\
\text { Influence }\end{array}$} & Summer & 49 & 42.24 & 43 & 6 & 87.76 & 12.24 & \multirow{3}{*}{$0.034^{\mathrm{a}}$} \\
\hline & Rainy & 31 & 26.72 & 20 & 11 & 64.52 & 35.48 & \\
\hline & Winter & 36 & 31.03 & 30 & 6 & 83.33 & 16.67 & \\
\hline \multirow{5}{*}{$\begin{array}{l}\text { Age of Birds } \\
\text { (Days) }\end{array}$} & $\leq 10$ & 26 & 22.41 & 23 & 3 & 88.46 & 11.54 & \multirow{5}{*}{$0.222^{\mathrm{a}}$} \\
\hline & 11 To $\leq 20$ & 32 & 27.59 & 27 & 5 & 84.38 & 15.63 & \\
\hline & 21 To $\leq 30$ & 38 & 32.76 & 29 & 9 & 76.32 & 23.68 & \\
\hline & 31 To $\leq 40$ & 12 & 10.34 & 7 & 5 & 58.33 & 41.67 & \\
\hline & $>40$ & 8 & 6.90 & 7 & 1 & 87.50 & 12.50 & \\
\hline
\end{tabular}

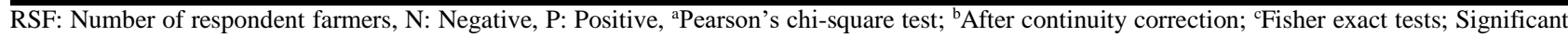
at $1 \%(\mathrm{P}<0.01)$, Significant at $5 \%(\mathrm{P}<0.05) ; \mathrm{n}=$ Number.

According to Table 4, some of the common biosecurity practices in broiler farms were encountered as study variables. In this accordance, our study transpired that visitor's access, pet in farm areas, feeder cleaning frequency, waterer cleaning frequency, and lastly, the seasonal variation had a significant relation with ND occurrence by $\mathrm{P}<0.5$. Likewise, Table 4 shows, ND positive farm of $24.14 \%$ had access to visitors and $6.9 \%$ no access to visitors. Alsahami et al. (2018) stated that free entry of visitors significantly $(\mathrm{P}<0.01)$ associated with higher seroprevalence to ND, agreed with our findings. Accordingly, pets on the farm or in the same premises are one of the important factors for assessing biosecurity. Access of pets or presence in farm areas also breaches the farm biosecurity which may imply the ND occurrence. In fact, good biosecurity could protect the poultry flocks from the ND as reported by the other authors (Yune and Abdela, 2017). On other side, farms practice the cleaning of waterer and feeder weekly had more trends to ND positive case by $38.46 \%$ and $35.14 \%$ respectively. Belgrad et al. (2018) reported that ND positive cases were higher for those who clean the waterer once per three or four weeks and feeder once in a week, these findings also suggested our result.
Additionally, cleaning is the second most effective element of biosecurity followed by disinfection (FAO 2008). The only regular cleaning and disinfecting activities by spraying inside and outside of the poultry shed was observed by Rimi et al. (2017). As Table 4 shows, the daily use of disinfectant reduced the ND positive case indicated by $5.41 \%$, while the farm never uses disinfectant placed $42.86 \%$. Likewise, Guan et al. (2014) suggested that disinfectant especially surface decontamination foam were more effective for the inactivation of Newcastle disease virus.

According to the Table 5, Binary logistic regression was performed to assess the impact of several factors on the likelihood that the broiler farm had an outbreak of Newcastle disease in the Barishal district of Bangladesh. The model contained ten independent variables (Farmers Training, Broiler Shed Location, Ventilation, Vaccination Status, Feeder Cleaning Frequency, Waterer Cleaning Frequency, Access of Visitors, Pets in The Farm or in Same Premises, Using Disinfectant and Seasonal Influence). 
Table 4. Biosecurity Practices in broiler farm Associated with ND Status

\begin{tabular}{|c|c|c|c|c|c|c|c|c|}
\hline \multirow{3}{*}{ Variables } & \multirow{3}{*}{ Category Level } & \multirow{2}{*}{\multicolumn{2}{|c|}{$\mathrm{RSF}$}} & \multicolumn{4}{|c|}{ ND Status } & \multirow{3}{*}{$\begin{array}{c}\mathrm{P}- \\
\text { Value }\end{array}$} \\
\hline & & & & \multicolumn{2}{|c|}{$\mathrm{n}=116$} & \multicolumn{2}{|c|}{$\%$} & \\
\hline & & (n) & $\%$ & $\mathrm{~N}$ & $\mathrm{P}$ & $\mathrm{N}$ & $\mathrm{P}$ & \\
\hline \multirow{2}{*}{ Access Of Visitors } & No & 29 & 25.00 & 27 & 2 & 93.10 & 6.90 & \multirow{2}{*}{$0.044^{\mathrm{a}}$} \\
\hline & Yes & 87 & 75.00 & 66 & 21 & 75.86 & 24.14 & \\
\hline \multirow{2}{*}{$\begin{array}{l}\text { Pets in the Farm or in } \\
\text { Same Premises }\end{array}$} & No & 81 & 69.83 & 70 & 11 & 86.42 & 13.58 & \multirow{2}{*}{$0.010^{\mathrm{a}}$} \\
\hline & Yes & 35 & 30.17 & 23 & 12 & 65.71 & 34.29 & \\
\hline \multirow{2}{*}{$\begin{array}{l}\text { Wild Birds Have } \\
\text { Contact }\end{array}$} & No & 24 & 20.69 & 20 & 4 & 83.33 & 16.67 & \multirow{2}{*}{$0.882^{b}$} \\
\hline & Yes & 92 & 79.31 & 73 & 19 & 79.35 & 20.65 & \\
\hline \multirow{2}{*}{$\begin{array}{l}\text { Farm Animals in } \\
\text { Same Premises }\end{array}$} & No & 74 & 63.79 & 62 & 12 & 83.78 & 16.22 & \multirow{2}{*}{$0.195^{\mathrm{a}}$} \\
\hline & Yes & 42 & 36.21 & 31 & 11 & 73.81 & 26.19 & \\
\hline \multirow{3}{*}{$\begin{array}{l}\text { Feeder Cleaning } \\
\text { Frequency }\end{array}$} & Weekly & 37 & 31.90 & 24 & 13 & 64.86 & 35.14 & \multirow{3}{*}{$0.018^{\mathrm{a}}$} \\
\hline & Daily & 53 & 45.69 & 46 & 7 & 86.79 & 13.21 & \\
\hline & Every Time After Use & 26 & 22.41 & 23 & 3 & 88.46 & 11.54 & \\
\hline \multirow{3}{*}{$\begin{array}{l}\text { Waterer Cleaning } \\
\text { Frequency }\end{array}$} & Weekly & 26 & 22.41 & 16 & 10 & 61.54 & 38.46 & \multirow{3}{*}{$0.022^{\mathrm{a}}$} \\
\hline & Daily & 48 & 41.38 & 40 & 8 & 83.33 & 16.67 & \\
\hline & Every Time After Use & 42 & 36.21 & 37 & 5 & 88.10 & 11.90 & \\
\hline \multirow{3}{*}{ Use of Disinfectant } & Not at All & 28 & 24.14 & 16 & 12 & 57.14 & 42.86 & \multirow{3}{*}{$0.001^{\mathrm{a}}$} \\
\hline & Often & 51 & 43.97 & 42 & 9 & 82.35 & 17.65 & \\
\hline & Daily & 37 & 31.90 & 35 & 2 & 94.59 & 5.41 & \\
\hline \multirow{4}{*}{$\begin{array}{l}\text { Disposal Of Dead } \\
\text { Birds }\end{array}$} & Thrown in Bush & 38 & 32.76 & 28 & 10 & 73.68 & 26.32 & \multirow{4}{*}{$0.616^{\mathrm{c}}$} \\
\hline & Thrown in Water & 21 & 18.10 & 17 & 4 & 80.95 & 19.05 & \\
\hline & Bury & 54 & 46.55 & 45 & 9 & 83.33 & 16.67 & \\
\hline & Burn & 3 & 2.59 & 3 & 0 & 100.0 & 0.00 & \\
\hline \multirow{3}{*}{ Disposal Of Litter } & Compost & 30 & 25.86 & 27 & 3 & 90.00 & 10.00 & \multirow{3}{*}{$0.106^{\mathrm{a}}$} \\
\hline & Thrown in Bush/Road Side & 49 & 42.24 & 35 & 14 & 71.43 & 28.57 & \\
\hline & Thrown in Water & 37 & 31.90 & 31 & 6 & 83.78 & 16.22 & \\
\hline
\end{tabular}

RSF: Number of respondent farmers, N: Negative, P: Positive, ${ }^{\text {a, }}$ Pearson's chi-square test; ${ }^{\text {b, }}$ After continuity correction; ${ }^{\mathrm{c},}$ Fisher exact tests; Significant at $1 \%$ (P<0.01), Significant at $5 \%(\mathrm{P}<0.05), \mathrm{n}=$ Number.

Table 5. Regression model of factors associated with broiler farms leads to Newcastle diseases occurrences.

\begin{tabular}{|c|c|c|c|c|c|c|c|}
\hline \multirow{2}{*}{ Variables } & \multirow{2}{*}{ Category Level } & \multirow{2}{*}{ B } & \multirow{2}{*}{ Wald } & \multirow{2}{*}{$\begin{array}{c}\text { P- } \\
\text { Value }\end{array}$} & \multirow{2}{*}{ O.R. } & \multicolumn{2}{|c|}{$95 \%$ C.I. for O.R. } \\
\hline & & & & & & Lower & Upper \\
\hline Farmers Training & $\begin{array}{l}\text { No } \\
\text { Yes }\end{array}$ & -3.688 & $\begin{array}{l}\text { Ref. } \\
5.758\end{array}$ & 0.016 & 0.025 & 0.001 & 0.509 \\
\hline $\begin{array}{l}\text { poultry shed } \\
\text { location }\end{array}$ & $\begin{array}{l}\text { Inside } \\
\text { Outside }\end{array}$ & -3.338 & $\begin{array}{l}\text { Ref. } \\
7.445\end{array}$ & 0.006 & 0.035 & 0.003 & 0.390 \\
\hline ventilation & $\begin{array}{l}\text { Insufficient } \\
\text { Sufficient }\end{array}$ & -0.091 & $\begin{array}{l}\text { Ref. } \\
0.009\end{array}$ & 0.923 & 0.913 & 0.145 & 5.737 \\
\hline Vaccination status & $\begin{array}{l}\text { No } \\
\text { Only ND } \\
\text { ND+Others }\end{array}$ & $\begin{array}{l}-4.088 \\
-4.468 \\
\end{array}$ & $\begin{array}{l}\text { Ref. } \\
6.057 \\
9.317 \\
\end{array}$ & $\begin{array}{l}0.014 \\
0.002 \\
\end{array}$ & $\begin{array}{l}0.017 \\
0.011 \\
\end{array}$ & $\begin{array}{l}0.001 \\
0.001 \\
\end{array}$ & $\begin{array}{l}0.435 \\
0.202 \\
\end{array}$ \\
\hline $\begin{array}{l}\text { Feeder cleaning } \\
\text { frequency }\end{array}$ & $\begin{array}{l}\text { Weekly } \\
\text { Daily } \\
\text { Every Time After Use }\end{array}$ & $\begin{array}{l}-0.413 \\
-2.015\end{array}$ & $\begin{array}{l}\text { Ref. } \\
0.110 \\
1.898 \\
\end{array}$ & $\begin{array}{l}0.741 \\
0.168\end{array}$ & $\begin{array}{l}0.662 \\
0.133\end{array}$ & $\begin{array}{l}0.058 \\
0.008\end{array}$ & $\begin{array}{l}7.609 \\
2.344\end{array}$ \\
\hline $\begin{array}{l}\text { Waterer cleaning } \\
\text { frequency }\end{array}$ & $\begin{array}{l}\text { Weekly } \\
\text { Daily } \\
\text { Every Time After Use }\end{array}$ & $\begin{array}{l}1.310 \\
1.909 \\
\end{array}$ & $\begin{array}{l}\text { Ref. } \\
0.598 \\
1.306 \\
\end{array}$ & $\begin{array}{l}0.439 \\
0.253 \\
\end{array}$ & $\begin{array}{l}3.707 \\
6.745 \\
\end{array}$ & $\begin{array}{l}0.134 \\
0.255 \\
\end{array}$ & $\begin{array}{l}102.576 \\
178.213 \\
\end{array}$ \\
\hline Access of visitors & $\begin{array}{l}\text { No } \\
\text { Yes }\end{array}$ & 2.068 & $\begin{array}{l}\text { Ref. } \\
2.066\end{array}$ & 0.151 & 7.908 & 0.471 & 132.677 \\
\hline $\begin{array}{l}\text { Pets in the farm or } \\
\text { in same premises }\end{array}$ & $\begin{array}{l}\text { No } \\
\text { Yes }\end{array}$ & 0.487 & $\begin{array}{l}\text { Ref. } \\
0.188\end{array}$ & 0.665 & 1.627 & 0.180 & 14.683 \\
\hline Using Disinfectant & $\begin{array}{l}\text { Not At All } \\
\text { Often } \\
\text { Daily }\end{array}$ & $\begin{array}{l}-2.374 \\
-4.473 \\
\end{array}$ & $\begin{array}{l}\text { Ref. } \\
3.669 \\
7.281 \\
\end{array}$ & $\begin{array}{l}0.055 \\
0.007 \\
\end{array}$ & $\begin{array}{l}0.093 \\
0.011 \\
\end{array}$ & $\begin{array}{l}0.008 \\
0.000 \\
\end{array}$ & $\begin{array}{l}1.057 \\
0.294 \\
\end{array}$ \\
\hline Seasonal Influence & $\begin{array}{l}\text { Summer } \\
\text { Rainy } \\
\text { Winter }\end{array}$ & $\begin{array}{l}1.164 \\
-0.243\end{array}$ & $\begin{array}{l}\text { Ref. } \\
1.098 \\
0.044\end{array}$ & $\begin{array}{l}0.295 \\
0.833\end{array}$ & $\begin{array}{l}3.204 \\
0.784\end{array}$ & $\begin{array}{l}0.363 \\
0.082\end{array}$ & $\begin{array}{c}28.270 \\
7.496\end{array}$ \\
\hline Constant & $\mathrm{R}^{2}=0.477(\mathrm{Cox} \& \mathrm{Sn}$ & $\begin{array}{l}3.323 \\
, 0.756\end{array}$ & $\begin{array}{r}1.909 \\
\text { Nagelk }\end{array}$ & $\begin{array}{l}0.167 \\
\text { ke R Sq }\end{array}$ & $\begin{array}{l}27.734 \\
\text { are) }\end{array}$ & & \\
\hline
\end{tabular}

Hosmer and Lemeshow Test P value: 0.921; Ref.= Reference category; Significant at $1 \%(\mathrm{P}<0.01)$, Significant at 5\% $(\mathrm{P}<0.05)$. C.I.= Confidence Interval; O.R. = Odd Ratio. 
The full model containing all predictors was statistically significant, $\chi 2(10, N=116)=75.109$, $\mathrm{P}<0.001$, indicating that the model was able to distinguish between farmers whose farm was positive and negative for Newcastle disease outbreak. The model as a whole explained between $47.7 \%$ (Cox and Snell R square) and $75.6 \%$ (Nagelkerke $\mathrm{R}$ squared) of the variance in Newcastle disease status, and correctly classified $90.2 \%$ of cases. As shown in Table 5, only four (Farmers training, Broiler shed location, Vaccination status, and Using disinfectant) of the independent variables made a unique statistically significant contribution to the model and all the four predictors had approximately similar strength on reporting Newcastle disease outbreak. Among the four significantly independent variables, the vaccination status (ND+ another vaccine) had had to record a lower odd ratio of 0.011 which are less than one, indicating that for every additional farm practices vaccine against ND with other diseases were 0.011 times less likely to the outbreak of ND in broiler. Additionally, this is also similar for them who using disinfectant daily in their broiler farm, controlling for other factors in the model. Hence, the $\mathrm{p}$-value $(\mathrm{P}>0.05)$ of Hosmer and Lemeshow test indicate the final model is fit. Although a total of 116 broiler farms in Barishal district in Bangladesh were included in the study, the sample size and geographic location of broiler farms might be the most likely reason for some of the very wide confidence intervals in the inferential analysis of several factors and subsequent disease outcome.

\section{Conclusion}

The present study implicated that poultry shed located inside the home yard having insufficient ventilation with inappropriate farm biosecurity measures relating irregular cleaning of feeder and waterer equipment, unfamiliar with the use of disinfectant regularly, visitor accession and pets or other animals in farm area were more recumbent to exposure of NDV. Likewise, the rainy season had an influence on ND occurrence. Another important factor vaccination, even though the prevalence of ND hindered by practicing only against NDV, but practicing with others vaccine against all possible pathogen are more prone to decreasing the chance of ND occurrence. However, the findings of this study implies that NDV infection can be greatly reduced in broiler farms by improving the level of common biosecurity practices, minimizing the potential risk factors and improving the farm management practices through training of farmers, awareness build-up, and enforcement of these practices on the farms. This study also identified areas in which further research could be on understanding the seroprevalence of ND with a larger sample sizes in layer birds as well as broiler. Therefore, updated epidemiological data on poultry diseases is essential that could be used to design prevention and control strategies.

\section{Acknowledgements}

The authors express their gratitude to the Research and Training Centre (RTC), Patuakhali Science and Technology University, Patuakhali, Bangladesh for supporting the study financially.

\section{Conflict of interest}

Authors declare that there is no conflict of interest.

\section{References}

Al-Garib SO, Gielkens ALJ, Koch G. 2003. Review of Newcastle disease virus with particular references to immunity and vaccination. World's Poultry Science Journal. (59): 185-197.

Al-Mamun M, Islam K, Rahman M. 2019. Occurrence of poultry diseases at Kishoregonj district of Bangladesh. MOJ Proteomics \& Bioinformatics. 8(1): 7-12, doi: 10.15406/mojpb.2019.08.00259

Alam M, Sultana S, Hassan M, Hasanuzzaman M, Faruk M. 2016. Socio-economic status of the farmers and economic analysis of poultry farming at Gazipur district in Bangladesh. International Journal of Natural Sciences. 4(2): 8-12, doi: 10.3329/ijns.v4i2.28598

Alexander DJ. 2000. Newcastle disease and other avian paramyxoviruses. Rev Sci Tech Off Int Epiz. 19(2): 443-462

Alsahami A, Ideris A, Omar A, Ramanoon SZ, Sadiq MB. 2018.Seroprevalence of Newcastle disease virus in backyard chickens and herd-level risk factors of Newcastle disease in poultry farms in Oman. International Journal of Veterinary Science and Medicine. 6(2): 186-191, doi: 10.1016/j.ijvsm.2018.06.004

Ameji ON, Abdu PA, Sa'idu L, Isa-Ochepa M. 2012. Knowledge of poultry diseases, biosecurity and husbandry practices among stakeholders in poultry production in Kogi state, Nigeria. Sokoto Journal of Veterinary Sciences. 10(2): 26-31

Belgrad JP, Rahman MA, Abdullah MS, Rashid MH, Sayeed MA, Anwer MS, Hoque MA. 2018. Newcastle disease sero and viro-prevalence in rural poultry in Chittagong, Bangladesh. Preventive Veterinary Medicine. 160(September)Elsevier,: 18-25, doi: 10.1016/j.prevetmed. 2018.09.015

Chukwudi OE, Chukwuemeka ED, Mary U. 2012. Newcastle disease virus shedding among healthy commercial chickens and its epidemiological importance. Pakistan Veterinary Journal. (32): 354-356

Das A, Ghosh P, Das A, Chowdhury S. 2018. Journal of Veterinary Medicine A Retrospective Analysis of Prevalence of Newcastle Disease and Infectious Bursal Disease in Poultry at Kishoreganj , Bangladesh. Journal of Veterinary Medicine and Health. 2(2): 108

Dimitrov K, Ramey A, Qiu X, Bahl J, Afonso C. 2016. Temporal, geographic, and host distribution of avian paramyxovirus 1 (Newcastle disease virus). Infection, Genetics and Evolution. (39): $22-34$

FAO. 2008. Biosecurity for Highly Pathogenic Avian Influenza, Rome.

Guan J, Chan M, Brooks BW, Rohonczy L. 2014. Inactivation of infectious bursal disease and Newcastle disease viruses at temperatures below $0 \mathrm{C}$ using chemical disinfectants. Avian diseases. 58(2): 249—254, doi: 10.1637/10697-101713-reg.1

Hasan AR, Ali M, Siddique M, Rahman M, Islam M. 2012. Clinical and Laboratory Diagnoses of Newcastle and Infectious Bursal Diseases of Chickens. Bangladesh Journal of Veterinary Medicine. 8(2): 131-140, doi: 10.3329/ bjvm.v8i2.11196

Ibitoye E, Jimoh A, Mungadi. 2013.A Retrospective (2007-2011) Analysis of Newcastle Disease Diagnosed at avian clinic of Veterinary Teaching Hospital, Usmanu Danfodiyo University Sokoto, Nigeria. Current Research in Poultry Science. 3: 12-17

Ibrahim RA, Cryer TL, Lafi SQ, Basha E abu, Good L, Tarazi YH. 2019. Identification of Escherichia coli from broiler chickens in Jordan, their antimicrobial resistance, gene characterization and the associated risk factors. BMC Veterinary Research. 15(159)BMC Veterinary Research,: 1-16 
Islam MR, Das BC, Hossain K, Lucky NS, Mostafa MG. 2003. A study on the occurrence of poultry diseases in Sylhet region of Bangladesh. International Journal of Poultry Science. 2(5): 354-356, doi: 10.3923/ijps.2003.354.356

Islam SS, Tahera T, Mondal R, Billah M. 2019. Women's participation in poultry farming to alleviate poverty from Batiaghata upazila under Khulna District. International Journal of Agronomy and Agricultural Research. 14(6): 32 38

Karim MJ. 2003. Proceeding of the 3rd International Poultry Show and Seminar of World Poultry Science Association. Bangladesh: BCFCC. Current Disease Pattern in Poultry with Special Emphasis on Parasites and Their Methods of Control. pp 119-123

Orajaka L, Adene D, Anene B etal. 1999. Seroprevalence of Newcastle disease in local chickens from Southeast derived savannah zone of Nigeria. Revue Elevage Mẻdecine Vẻtẻrinaire Pays Tropicaux. 52(3-4): 185-188

Permin A. 1997. Proceeding of International Network for Family Poultry (INFPD) workshop, M'Bour, Senegal, Dec. 9-13. A Survey of the Disease Status of Scavenging Poultry in the Morogoro Region Tanzania. pp 91-93

Rahaman MM, Hossain MM, Aktaruzzaman M, Hossain FMA, Paul S. 2011. Retrospective Study of Newcastle Disease: A Case of Gazipur in Bangladesh. Iternational Journal of Sustaniable Agricultural Techniques. 7(3): 66-69

Rahman MA, Adhikary GN. 2016. Poultry Diseases in Some Selected Areas in Sylhet District of. Journal of Sylhet Agricultural University. 3(1): 1-8

Rahman MM, Hossain MM, Aktaruzzaman M, Hossain FMA, Paul S. 2011. Retrospective Study of Newcastle Disease: A Cases Of Gazipur in Bangladesh. International Journal of Sustainable Agricultural Technique. 7(3): 66-69
Rahman M, Islam M, Ullah M, Adeyl F. 2002. Study on the Scientific Knowledge and Managemental Skill in Commercial Broiler Farming Programme at the Farmers Level of Rajshahi District. OnLine J Biol Sci. 2(11): 767-768

Rimi NA, Sultana R, Muhsina M, Uddin B, Haider N, Nahar N, Zeidner N, Sturm-Ramirez K, Luby SP. 2017.Biosecurity Conditions in Small Commercial Chicken Farms, Bangladesh 2011-2012. EcoHealth. 14(2): 244-258, doi: 10.1007/ s10393-017-1224-2

Shahjahan M, Bhuiyan AKFH. 2016. Socio-economic condition and indigenous poultry production scenario in a selected cluster area of Bangladesh. Asian-Australasian Journal of Bioscience and Biotechnology. 1(3): 557-563

Swayne DE, Jackwood MP. 2008. Pathobiology of avian influenza virus infections in birds and mammals. In: Swayne DE (editor), Avian Influenza. First ed. Blackwel, Ames, Iowa, USA, pp 87-122

Thrusfield MV. 2005. Criteria for Success of Questionnaire. In: Veterinary Epidemiology. $3^{\text {rd }}$ edn, Oxford, UK: Blackwell Science. P. 189-213.

Tu T, Phuc K, Dinh N, Et A. 1998.Vietnam trials with a thermostable Newcastle disease vaccine (strain I2) in experimental and village chickens. Preventive Veterinary Medicine. 34(2-3): 205-214

Wakawa AM, Abdu PA, Oladele SB, Sa'idu L, Mohammed SB. 2012. Risk factors for the occurrence and spread of Highly Pathogenic Avian Influenza H5N1 incommercial poultry farms in Kano, Nigeria. Sokoto Journal of Veterinary Sciences. 10(2): 40-51

Yune N, Abdela N. 2017. Update on epidemiology, diagnosis and control technique of Newcastle disease. Journal of Veterianry Science Technology. 8(2): 429 